OPEN ACCESS

Edited by:

Amy lckowitz,

Center for International Forestry

Research (CIFOR), Indonesia

Reviewed by:

Jonathan Padwe,

University of Hawail at Manoa,

United States

C. Anne Claus,

American University, United States

*Correspondence: Terence C. Sunderland terry.sunderland@ubc.ca

Specialty section: This article was submitted to

People and Forests,

a section of the journal Frontiers in Forests and Global

Change

Received: 25 June 2019 Accepted: 28 February 2020 Published: 18 March 2020

Citation:

Sunderland TC and Vasquez W (2020)

Forest Conservation, Rights, and Diets: Untangling the Issues. Front. For. Glob. Change 3:29. doi: 10.3389/ffgc.2020.00029

\section{Forest Conservation, Rights, and Diets: Untangling the Issues}

\author{
Terence C. Sunderland ${ }^{1,2 *}$ and Winy Vasquez ${ }^{1}$ \\ ${ }^{1}$ Faculty of Forestry, University of British Columbia, Vancouver, BC, Canada, ${ }^{2}$ Centre for International Forestry Research, \\ Bogor, Indonesia
}

Recent research has highlighted the contributions of forests and tree-based systems to both dietary diversity and nutrition as well as agricultural production in the form of tree-based ecosystem services. Wild foods provide a significant nutritional contribution to the diets of rural dwellers, the majority of whom would be classified as some of the world's poorest. Yet, despite the important human-forest interactions and relative degrees of forest dependency, access to much of the global forest estate is increasingly regulated under the guise of biodiversity conservation. How this restricted access plays out when the "right to food" is a deeply enshrined human right has been deeply contested, particularly with regard to land annexation. This paper outlines the critical issues related to dietary diversity and nutrition in the context of the availability of wild foods juxtaposed with the growing call for the annexation of land for conservation. We suggest that a more integrated and equitable approach to land management that embraces both biodiversity conservation and broader food security and nutrition goals can provide multiple benefits, while mitigating local conflicts. As such, a rights-based approach to conservation and an embracing of broader landscape perspectives are possible strategies to achieve these seemingly conflicting agendas.

Keywords: rights, dietary diversity, biodiversity conservation, food security, nutrition

\section{INTRODUCTION}

For the majority of our history we humans have sustained ourselves by foraging edible plants and hunting animals encountered in grasslands, forests and other wild habitats (Smith et al., 1983). Indeed, our evolutionary development is almost entirely based on a complex system of hunting and gathering that was able to provide a varied and nutritious diet (Crittenden and Schnorr, 2016). Even today, remaining bands of hunter gatherers exhibit greater dietary diversity, nutrition and health than the majority of their more sedentary counterparts (Dounias and Froment, 2006; Reyes-Garcia et al., 2019).

Around 12,000 years ago, agriculture simultaneously emerged in various parts of the world, representing a food system that is very much dominant today. This "agricultural revolution" (Gordon et al., 2016), resulted in the settlement of former forager communities to focus on the production of a small variety of crops and livestock. Sedentary agriculture increased the overall volume of food, yet ultimately led to a more simplified diet. It also resulted in large swathes of wild habitats being permanently transformed into agricultural landscapes, unprecedented population growth and the emergence of cities and society as we now know it (Harari, 2016).

However, despite the overwhelming dominance of contemporary agriculture, people remain dependent on forests in myriad ways (Agrawal et al., 2013). Forests and the resources within them 
provide a wide array of goods and services for those in their proximity and also to wider society (HLPE, 2017a). Of the estimated 1.6 billion people said to be dependent on forests in some way (FAO, 2014a) many derive much of their dietary diversity and, ultimately, nutrition and broader health, from wild foods (Ickowitz et al., 2014; Powell et al., 2015).

Contemporary agriculture currently focuses on the production of large quantities of a limited number of crops; i.e., the main thrust of global food security remains an emphasis on the production of calories (Vandermeer et al., 2018; Ickowitz et al., 2019). Monocultures of grains and other high-intensity crops require land and much of the historical and contemporary expansion of agriculture has come at the expense of natural habitats, notably forests (Gibbs et al., 2010) with a significant proportion of this forest conversion, primarily for commodity crops, being permanent (Curtis et al., 2018).

We now grow more food than ever before and, in terms of overall production, sufficient food is available to feed the current and projected future populations (Holt-Giménez et al., 2012; HLPE, 2017b). Inequalities in markets, income and distribution, however, mean that vast numbers of the global population are malnourished in a number of ways. This can include undernutrition, being micronutrient deficient, or overweight, and/or obese. The "feast or famine" (Darnton-Hill and Coyne, 1998) dichotomy that characterizes the global food system suggests that we need a dramatic re-thinking of how we feed the global population (HLPE, 2017b; Vandermeer et al., 2018).

In addition to uncertain dietary outcomes, contemporary agriculture has also resulted in significant environmental damage, arguably to the limits of planetary boundaries (Campbell et al., 2017). Aside from being a major driver of deforestation, agriculture accounts for an estimated one third of greenhouse gas emissions through the intensive reliance on fossil fuels (Springmann et al., 2018) and soil erosion from agricultural tillage currently exceeds soil formation (Amundson et al., 2015). Up to $70 \%$ of the world's freshwater is appropriated to nourish crops and livestock (Tanentzap et al., 2015) and the loss of ecosystem services through habitat conversion is affecting the resilience of many agricultural systems (Reed et al., 2017). Thus, the global food system is currently characterized by less than adequate nutrition outcomes, compounded by an environment that is being increasingly degraded to support it.

In recent years considerable evidence has emerged that forests and other wild habitats continue to contribute to the dietary diversity and overall nutrition of hundreds of millions of people, particularly those affected by chronic poverty (Ickowitz et al., 2014; HLPE, 2017a). Further evidence also suggests that more complex biodiverse environments are linked with better nutrition outcomes (Sunderland, 2011; Dawson et al., 2019). This is especially important for rural populations with limited market access or who are suffering the effects of poverty and are thus not able to purchase sufficient food to nourish themselves or their families. Wild foods provide people with much needed dietary diversity that includes essential micronutrients (Powell et al., 2015). However, despite high level policy recommendations that better access to wild foods be facilitated, especially those within forests (see Vira et al., 2015; HLPE, 2017a), there is a conflicting movement to protect and isolate vast areas of the global forest estate for the conservation of biodiversity (Sylvester et al., 2016; Perfecto et al., 2019). The International Union for Conservation of Nature (IUCN) estimates that around 15\% of the world's land area and 7\% of the world's oceans have been designated as protected areas (PAs), many of which restrict access for local communities (IUCN, 2019). This is slightly $<10$ and $17 \%$ for marine and terrestrial protection outlined in the commitments of the Aichi Targets for 2020. PAs and the global hunger statistics may, at first glance, seem like two unrelated global challenges, or even competing interests, but they are in fact inextricably interlinked.

Combating malnutrition is a critical development objective due to the long-term and far-reaching health and socioeconomic implications of malnutrition such as, compromised cognitive development in children (Cawthorn and Hoffman, 2015), childhood stunting ( $\mathrm{Fa}$ et al., 2015; Nielsen et al., 2018) and increased susceptibility to non-communicable diseases (Popkin, 2001; Vinceti et al., 2013; Savage et al., 2019). Biodiversity conservation, is likewise an important global objective, due to the rapid and ongoing depletion of species and concomitant habitat destruction occurring worldwide, especially in the face of a changing climate (Morales-Hidalgo et al., 2015). In common with malnutrition, biodiversity loss has far-reaching impacts, which negatively impacts both humans and nature. While interest in PA-driven conservation as an effective means to safeguard biodiversity continues to grow, so has the parallel global movement to eradicate hunger and malnutrition. Can these two objectives be achieved in concert?

\section{HOW DO FORESTS PLAY A ROLE IN DIETS AND NUTRITION?}

\section{Contribution of Wild Foods to Diets}

An important contribution of forests to food security is in the form of the direct provisioning of wild foods such as edible plants, nuts, seeds and wild meat, or bushmeat (Rasmussen et al., 2017). Research has demonstrated that many rural populations that live in or around forested areas rely, to varying degrees, on the harvesting of wild foods to help meet their dietary needs (Broegaard et al., 2016; Rowland et al., 2017). Positive relationships between tree cover and dietary diversity have been identified in Malawi (Johnson et al., 2013; Hall et al., 2019) and also in the vast and diverse archipelago of Indonesia (Ickowitz et al., 2016). However, it is a series of multi-country meta-analyses that provide the most compelling evidence for the positive linkages between forests and diets. Ickowitz et al. (2014), for example, found a positive relationship between tree cover and dietary diversity among the diets of children in 21 African countries. Rasolofson et al. (2018) found the same relationship in their 27-country analysis on the same continent. A global comparative analysis found that $77 \%$ of rural households surveyed engaged in wild food collection, highlighting that such harvesting is an integral part of many livelihood strategies, particularly in developing countries (Hickey et al., 2016). Looking at the issue from a different perspective, Galway et al. (2018) 
noted that deforestation and the loss of forest cover around dwellings and agricultural fields resulted in poorer dietary outcomes for children in sub-Saharan Africa.

The harvesting of wild foods can contribute to food security by allowing rural dwellers to access these nutritious foods when they may otherwise not have other sources of sustenance (Boedecker et al., 2014). Access to wild foods is also an important part of achieving overall food security as it can help mitigate hardships brought on by internal and external shocks such as droughts, war, illness, and/or failing crops (Pouliot and Treue, 2013; Clements et al., 2014). The collection of wild foods can also bring resilience to traditional agricultural systems by providing a safety net in case of crop failures, pests infestations or crop raiding by animals, a common occurrence in and around PAs (Nyahongo et al., 2009; Pouliot and Treue, 2013; Schulte-Herbrüggen et al., 2013; Wunder et al., 2014; Cawthorn and Hoffman, 2015).

While an agricultural system can provide a family with a few staple food crops and help fulfill the daily caloric requirements of an individual, it doesn't always adequately provide a diverse and nutritious diet when compared to that possible when supplemented with locally available wild foods (Fischer et al., 2017; Nakamura and Hanazaki, 2017). Studies have shown that increased agricultural production has, in some cases, actually led to lower quality diets that are comprised of calorie rich food which lack important micronutrients such as iron, zinc and vitamin B12 (Cawthorn and Hoffman, 2015; Powell et al., 2015; Ickowitz et al., 2016). Thus, harvesting wild foods can provide dietary diversity and help combat micronutrient deficiencies, also known as "hidden hunger" (Ickowitz et al., 2014; Fa et al., 2015; Nielsen et al., 2018). Micronutrient deficiency is an important aspect of malnutrition that can have dire consequences in vulnerable sectors of the population such as young children and can lead to childhood stunting, which has life-long consequences (Temsah et al., 2018).

Although wild foods do not necessarily contribute a large percentage of calories to the diets of rural households, they have been found, in several studies, to contribute to a greater proportion of essential vitamins and minerals (Powell et al., 2015; Asprilla-Perea and Díaz-Puente, 2019). In an assessment of the contribution of natural resources to the nutritional status of the local population in a PA in Gabon, Blaney et al. (2009), found that the consumption of natural resources by children aged 5 to 9 , was the best predictor for nutritional status. While natural foods only contributed to $12 \%$ of the energy requirements of villagers of the Gamba Complex of Gabon, they contributed an estimated $82 \%$ of protein, 36\% of Vitamin A and $20 \%$ of iron requirements (Blaney et al., 2009).

Hunting for bushmeat has long been a controversial issue due to concerns over the conservation impacts of wildlife depletion but bushmeat hunting is also important in helping rural households to achieve food security (Fa et al., 2009; Nyahongo et al., 2009; Rentsch and Damon, 2013; Golden et al., 2014; Cawthorn and Hoffman, 2015; Reuter et al., 2016; Nielsen et al., 2018). In the Abun region of West Papua, Indonesia, hunting has proved to be an important factor in fighting food insecurity, as wildmeat accounted for $49 \%$ of the diets of respondents (Pattiselanno and Lubis, 2014). Bushmeat hunting around the world remains an important source of protein and, more importantly micronutrients, for many rural households and can provide vulnerable populations such as children with important micronutrients (Golden et al., 2011; Van Vliet et al., 2015).

\section{Health}

Despite "western" divisions between food, medicine and health, natural resources continue to be an important contributor to health and well-being for many communities (Heywood, 2011). Access to wild foods is therefore important for human health, since nutrition and health are inherently linked. The impact of a loss of medicinal plants and nutritious diets can be seen in many indigenous communities that have undergone nutrition transitions. For example, Indigenous communities in Canada (Binnema and Niemi, 2006; Damman et al., 2008), Argentina (Damman et al., 2008), Sri Lanka (Weerasekara et al., 2018), the Eastern Mediterranean (Heywood, 2011) and Borneo (Dounias et al., 2007) have all undergone nutritional transitions away from their traditional diets. This dietary shift toward a narrower range of foods that are higher in fat, sugar, salt and refined carbohydrates has led to documented increases in the prevalence of non-communicable diseases such as cardiovascular disease and diabetes in the affected populations (Popkin, 2001; Albala et al., 2002; Kuhnlein et al., 2004; Damman et al., 2008; Lourenço et al., 2008; Savage et al., 2019). This has been due to both an increase in a nutritionally poor diets that makes individuals more susceptible to disease and illness, as well as a decrease in access to traditional medicinal plants. In Madagascar, Golden et al. (2011) found that a reduction in wild meat consumption, either by restricted access or wildlife depletion, could lead to a predicted $29 \%$ increase in children with anemia and a tripling of anemia in children in the poorest households (Golden et al., 2011). Likewise, in Cameroon, Tata et al. (2019) found incidences of anemia in women was far less prevalent where people had access to leafy forest vegetables. Thus, the benefits of wild foods go beyond the mere consumptive.

\section{CONSERVATION, RIGHTS, AND ACCESS}

Biodiversity conservation, as we relate to it, is a relatively modern construct. The creation of designated PAs is ultimately rooted in the western perspective of nature as untouched, uninhabited and unaltered (Neumann, 2002). This notion of pristine nature is, however, fails to recognize how people have been altering their landscapes for centuries and these altered landscapes have thus been classified as "natural" and "wild" (Shafer, 2015; Massé, 2016; Anaya and Espírito-Santo, 2018). Consequently, the dominant approach to conservation throughout the twentieth century was through the establishment of PAs from which people were essentially excluded. This model of conservation came to dominate twentieth century thinking, drawing primarily from the well-known North American networks of National Parks (Adams, 2004; Hutton et al., 2005).

However, there is often an inherent asymmetry in the costs and benefits of biodiversity conservation through protectionism, particularly in developing countries. While the multiple benefits 
of biodiversity conservation accrue at the national and global levels, the costs of PAs are often borne by local communities (Arjunan et al., 2006) particularly in terms of loss of access to resources. In this regard, many conservation initiatives around the world have had a long history of decoupling food security from biodiversity conservation by failing to understand the important role that natural resources play in the healthy and nutritious diets of rural populations (Powell et al., 2015; Sylvester et al., 2016) and conversely neglecting the important stewardship role that indigenous people play in natural resource management (Garnett et al., 2018). PAs can contribute to food insecurity through a variety of pathways such as a loss of direct access to the harvesting of wild foods (Nakamura and Hanazaki, 2017), loss of livestock due to predation by wildlife (Banerjee, 2012; Givá and Raitio, 2017), loss of access to water bodies used for irrigation or drinking water (Adhikari et al., 2009; N'Danikou et al., 2017), loss of fuelwood for cooking (Banerjee, 2012), loss of traditional knowledge (Turner and Turner, 2008; Desmet, 2016), and loss of access to markets and increased food prices due to tourism (Rosendo et al., 2011; Bennett and Dearden, 2014).

The proximity of local populations living in and around PAs has caused tensions in many parts of the world, which has, in some cases, resulted in conflict (West et al., 2006). The number of documented abuses of power and human rights due to the establishment, management and policing of PAs has been so prolific that the seriousness of the problem was recognized at an international level as early as 1982 at the Third World Park Congress (WPC), but a new agreement highlighting the problem was not reached until the 5th WPC in 2003 (IUCN, 2005). At this event, the Durban Accord was established to represent a shift in thinking that recognized the need to involve indigenous communities and address their needs in the context of PA establishment and management (Adams and Hutton, 2007). This also led to the launching in 2009 of the Conservation Initiative on Human rights, established by the largest conservation organizations to integrate and protect human rights in the design and implementation of conservation.

However, despite these movements toward respecting basic rights in contested landscapes, mounting evidence of human rights violations with regards to food access in PAs, land annexation for conservation has continued to grow along with enforcement to restrict access for harvesting wild resources (Sylvester et al., 2016; Newing and Perram, 2019). A case in point are the recent accusations leveled at the World Wildlife Fund who are being accused of significant human rights abuses in terms of over-zealous enforcement and restricting access to lands formerly utilized as a source of forest products ${ }^{1}$.

Traditional preservationist approaches to conserving our natural heritage have made way in the past 30 years to a more participatory and people-centered approach. Indeed, in the past decade or so, the majority of newly-created PAs fall within the lower end of the IUCN categories that allow for some level of subsistence use and management by local communities. Naidoo et al. (2019), in a comprehensive global analysis of the economic

\footnotetext{
${ }^{1}$ https://www.buzzfeednews.com/article/tomwarren/wwf-world-wide-fundnature-parks-torture-death
}

impacts of PA's show that where access and rights are respected, human well-being can be positively impacted by conservation implementation. Thus, sustainable use of selected resources, particularly wild foods, would suggest that there is greater scope for the integration of human use, and management, in many PAs.

However, while the conservation community has made increasing strives in recent decades to move away from what is described as "fortress conservation" approaches (Brockington, 2002) and toward community-based natural resource management that take into account local concerns and livelihoods, there remain persistent concerns with regard to a general disregard to effectively implementing "rights-based approaches" to conservation (Campese et al., 2009-see also Box 1). This is particularly concerning given recent calls to increase the area for biodiversity conservation to $50 \%$ of terrestrial land, or "half-Earth" (Wilson, 2016). The feasibility of such a proposition has been questioned given current human needs (Buscher et al., 2017), particularly for global food security (Mehrabi et al., 2018). However, the debate around such a proposition characterizes the dichotomy between the twin imperative of conserving global biodiversity while achieving a just, equitable and healthy food system. Despite the right to food $^{2}$ being enshrined in the human rights commitments of many nations around the world (see Box 2), these rights seem to not be factored in to the debate surrounding the need to achieve commitments toward biodiversity conservation.

\section{RECONCILING RIGHTS AND ACCESS TO ENSURE DIETARY DIVERSITY}

While biodiversity conservation is an important goal in a time when climate change and biodiversity loss are both real threats to human societies, clearly this must only take place when the underlying power relations that displace, restrict, enforce and result in significant social inequities, are addressed (Newing and Perram, 2019). Despite the majority of recently establish PAs falling within IUCN categories that allow multiple use, rights, tenure and access remain issues of contention within the traditional biodiversity conservation approach (Mollett and Kepe, 2018). As nation states attempt to achieve commitments to increase the area of land committed to conservation due to their global commitments, how can this be reconciled with achieving, or maintaining, food security and nutrition goals?

As stated previously, many PAs around the world have resulted in the loss of land rights and food access for local populations which has in turn negatively impacted the diets and nutrition of nearby communities. In order to prevent some of these impacts it is important to understand how management strategies can lead to food insecurity. Enlisting new initiatives to alleviate food insecurity and biodiversity loss will thus require the involvement of multiple disciplines to contribute innovative ways forward (Brockington et al., 2006; Timko and Satterfield, 2008).

\footnotetext{
2 "The right to adequate food is realized when every man, woman and child, alone or in community with others, have physical and economic access at all times to adequate food or means for its procurement." CESCR General Comment No. 12: The Right to Adequate Food (Art. 11).
} 
BOX 1 | Principles of the conservation initiative on human rights.

RESPECT HUMAN RIGHTS Respect internationally proclaimed human rights and make sure that we do not contribute to infringements of human rights while pursuing our mission.

PROMOTE HUMAN RIGHTS WITHIN CONSERVATION PROGRAMS Support and promote the protection and realization of human rights within the scope of our conservation programs.

PROTECT THE VULNERABLE Make special efforts to avoid harm to those who are vulnerable to infringements of their rights and to support the protection and fulfillment of their rights within the scope of our conservation programs.

ENCOURAGE GOOD GOVERNANCE Support the improvement of governance systems that can secure the rights of indigenous peoples and local communities in the context of our work on conservation and sustainable natural resource use, including elements such as legal, policy and institutional frameworks, and procedures for equitable participation and accountability.

Source: www.thecihr.org

BOX 2 | The right to food: Selected policies and legislative framework related to food security.

1941: U.S. President Franklin D. Roosevelt includes right to food one of the freedoms: "The freedom from want."

1948: Universal Declaration of Human Rights recognizes the right to food as part of the right to an adequate standard of living.

1966: The International Covenant on Economic, Social and Cultural Rights, reiterates the Universal Declaration of Human Rights with regard to be free from hunger.

1974: At the inaugural World Food Conference, 135 participating countries issued the Universal Declaration on the Eradication of Hunger and malnutrition which declared that "[e]very man, woman and child has the inalienable right to be free from hunger and malnutrition in order to develop fully and maintain their physical and mental faculties" (UN General Assembly, 1975, art. 1).

1975: The IUCN passed the Kinshasa Resolution on the protection of the "traditional ways of life" and called on governments to halt the displacement and relocation of people due to PA establishment (Adams and Hutton, 2007).

1996: The World Food Summit resulted in highlighting food security as a new global development goal. During this summit, food security was defined as "exists[ing] when all people, at all times, have physical and economic access to sufficient, safe and nutritious food that meets their dietary needs and food preferences for an active and healthy life" (World Food Summit, 1996).

2003: Durban Action Plan, outcome 5 "The rights of indigenous peoples, including mobile indigenous peoples, and local communities are secured in relation to natural resources and biodiversity conservation". http://danadeclaration.org/pdf/durbanactioneng.pdf

2004: The Convention on Biological Diversity called for the recognition of "the economic and socio-cultural costs and impacts arising from the establishment and maintenance of protected areas, particularly for indigenous and local communities, and (an adjustment of) policies to ensure that such costs and impacts - including the cost of livelihood opportunities forgone-are equitably compensated". COP 8 Decision VIII/23: https://www.cbd.int/decision/cop/?id=11037

2007: Establishment of the United Nations Declaration on the Rights of Indigenous Peoples (UNDRIP) affirmed the rights, survival, dignity and well-being of Indigenous people as well as safeguard the individual and collective rights of Indigenous people that may not be addressed by other human rights charters.

2009: Adoption of the Optional Protocol to the International Covenant on Economic, Social and Cultural Rights, making the right to food justiciable at the international level.

2012: UN Zero Hunger Challenge, which calls for sustainable food systems, an end to rural poverty, adaptation of all food systems to eliminate loss or waste of food, increase access to adequate food and healthy diets for all people all year round and finally, for an end to malnutrition in all its forms. https://www.un.org/zerohunger

2015: Sustainable Development Goals: SDG2, Target 1: "End the global hunger crisis and ensure all people, especially the poor, have access to sufficient and nutritious food". https://www.mdgmonitor.org/sdg2-end-hunger-achieve-food-security-and-improved-nutrition-and-promote-sustainable-agriculture

A move toward an increased recognition of synergies, rather than the trade-offs, between food security and biodiversity conservation presents an opportunity for the emergence of new conservation frameworks that build on rights-based approaches, food sovereignty principles, and participatory-conservation to rethink how PA enactment and enforcement is approached (Perfecto et al., 2019). As Broegaard et al. (2016) point out, within a landscape, nutritional outcomes are determined as much by access to resources that comprise rural diets as much as food production. Yet the inalienable right to be free from hunger is still denied for many rural populations that live within or adjacent to PA's, where there remains a strong emphasis on enforcement and restricted access.

While biodiversity conservation remains embedded in the paradigm of PAs, it is known that much of the world's biodiversity actually occurs in areas not under formal protection, but often in complex multi-functional landscape mosaics (Cox and Underwood, 2011; Gray et al., 2016). Such landscapes are often characterized by remnants of trees, either retained, planted or regenerated, intermixed with small-scale agricultural production systems. Indeed, it is estimated that between 35\% (Ricciardi et al., 2018) and 70-80\% (FAO, 2014b) of the world's food is actually grown by these smallholders who often manage such systems for a whole suite of products and ecosystem service benefits such as pollination, climate regulation, nutrient cycling etc. (Padoch and Sunderland, 2014; Baudron et al., 2019). There is increasing evidence of the myriad ways that forests and trees sustain agriculture when there is integration, rather than segregation, of function at the landscape scale (Reed et al., 2017). Such complex systems are also more resilient to both economic and environmental shocks (Wunder et al., 2014). This matrix provides a suite of agricultural products but also facilitates access to wild foods and other resources.

Interestingly, in recent years, research has begun to question the very premise of conservation in terms of the pristine 
nature of many of our wild places. It is currently emerging that vast tracts of the forested areas we have assumed to be thought of as pristine nature are in fact artifacts of millennia of human use and intervention. These include large areas of the Amazon (Levis et al., 2017; Maezumi et al., 2018) and Congo Basins (Osilisly et al., 2013; Lupo et al., 2015). In both forest blocks, extensive historical evidence has been found showing large settlements, anthropogenic burning, previous plant domestication and distribution, mining, agroforestry and crop production were prevalent.

This, of course, does not suggest that such forest formations are not worth conserving. Clearly, because of their considerable, and often unique, levels of biodiversity, as well as their carbon value, essential for climate change mitigation, they are. However, it should be recognized that, in many instances, their current manifestation is due to human influence. Given that indigenous peoples currently manage or have tenure rights over at least a quarter of the world's land surface which intersects with around $40 \%$ of terrestrial PAs and ecologically intact landscapes (Garnett et al., 2018), surely there is scope for these "gatekeepers" (Mackelworth and Carić, 2009) to be increasingly integrated into the establishment and management of conservation initiatives whereby both biodiversity conservation and livelihood goals are achieved in concert.

For example, in a meta-analysis of 55 PA's in developing countries, Andrade and Rhodes (2012) found the variable that most influenced the level of compliance with PA policies was the level of involvement of local communities in decisionmaking processes. Such evidence therefore gives further credence to the call for rights-based approaches which recognizes and respects the rights of local communities. Chhatre and Agrawal (2009) likewise found that higher levels of involvement and decision-making power of local communities led to more favorable conservation outcomes. In addition, the findings of Naidoo et al. (2019) that lower levels of protection within PA's, respecting usufruct rights of local communities, notably access to wild food resources, can lead to positive livelihood and conservation outcomes. A further meta-analysis of 165 PAs found that those that were associated with a positive socioeconomic outcome were more likely to also report positive conservation outcomes and thus demonstrated that conservation and food security goals are not antagonistic (Oldekop et al., 2016). Therein lies an opportunity to rethink how PAs are enacted and managed in order to support both biodiversity conservation and food security.

Thus, rights-based approaches to conservation will be one key instrument in moving toward more salient conservation policies that integrate the fundamental "right to food" by helping to identify rights-holders and duty-bearers to better inform PA management (Young et al., 2004; He and Cliquet, 2014; Newing and Perram, 2019). Adopting such an approach to conservation will present its own set of challenges, such as funding, lack of expertise and/or government capacity and competing rights, but it is a necessary step forward that can help to increase both conservation and food security (He and Cliquet, 2014; Kraak, 2018). In some cases, a rights-based approach will require the dissemination of power within PAs in favor of more egalitarian, bottom-up approaches such as communitybased conservation projects and livelihoods-based conservation (Campese et al., 2009).

Rights-based approaches can also increase the resilience of both humans and nature by supporting both social and environmental justice through collaboration and shared responsibility (Walsh-Dilley et al., 2016). Using a rightsbased approach to empower local communities to make their own management decisions around harvesting, logging and other resources practices can actually increase conservation outcomes as an increase in rights and responsibilities decreases unsustainable harvesting practices (Nielsen et al., 2018).

In a recent synthesis report on "Sustainable Forestry for Food Security and Nutrition" commissioned by the Committee of World Food Security (CFS) a series of recommendations were proposed and adopted by the CFS (HLPE, 2017a). This potentially represents the greatest leverage to include forests and trees onto the global food security agenda, even as a significant proportion of the forest estate is being increasingly allocated for conservation. We now have a much deeper understanding of the mechanisms as to how sustainable forest management contributes to food security and nutrition, but this contribution could be increased significantly through priority actions to:

1. Provide secure land and forest tenure and equitable access to resources.

2. Recognize and integrate the contribution of forests to food security and nutrition in forest policies.

3. Improve the alignment of food security and nutrition policies across the agriculture, forestry, livestock, fisheries, energy, mining and other relevant sectors.

4. Increase access by small forest and farmholders and their organizations to business skills, training, credit, technology, extension services and insurance.

5. Integrate gender equality in the formation, implementation and evaluation of relevant forest policies, and in investment strategies.

6. Strengthen the collection and timely dissemination of data relevant to policy-making on the contribution of forests and trees to food security and nutrition (Source: HLPE, 2017a).

It is evidently clear that a more holistic approach to conservation, forests management and food security can contribute to more successful outcomes for each sector, rather than the current siloed and detached focus on them in their singularity. Managing landscapes in an integrated manner for such multiple benefits is but one way forward (Sayer et al., 2013; Reed et al., 2016), and it has been suggested that various and diverse landscape configurations can provide multiple benefits for both conservation and agriculture (Rasmussen et al., 2019). Of course, global food security cannot be achieved by such an approach alone, but with the current emphasis on calories and monocultures the broader recognition of natural systems in the provision of diverse and nutritious diets is very timely. Integrating and respecting rights into our global conservation network is also long overdue, perhaps the implementation of a more "convivial conservation" as outlined by Büscher and Fletcher 
(2019: 283), a "post-capitalist approach to conservation and promotes radical equity, structural transformation and environmental justice...to create a more equal and sustainable world."

\section{IN CONCLUSION}

As the contribution of forests and tree-based systems continues to be recognized so does the opportunity to reconcile conservation in PAs with the rights to food in these spaces. With the increasingly growing demand to conserve more land and seascapes and reach the goals set out by global treaties it is now more important than ever to move forward with more inclusive management programs that do not jeopardize human livelihoods. As the amount of land that is set aside for the creation or expansion of PAs continues to grow so does the opportunity to recognize and rework broken management schemes that do not accurately reflect the social costs of conservation, the burden of which is most heavily felt by the poor and disfranchised parts of the population. While the recognition of rights-based approaches to conservation and rights to food will help alleviate food insecurity and malnutrition, it is but one strategy to ensure a more sustainable and equitable future.

Likewise, increasingly loud calls for a more ecologically friendly agriculture suggest there is developing interest in promoting long-term sustainability in the agricultural sector over production alone (DeClerck et al., 2011; Campanhola and Pandey, 2019; Ickowitz et al., 2019). Extensive evidence is emerging that breaking down the barriers between agriculture

\section{REFERENCES}

Adams, W. M. (2004). Against Extinction: the Story of Conservation. London: Earthscan.

Adams, W. M., and Hutton, J. (2007). People, parks and poverty: political ecology and biodiversity conservation. Conserv. Soc. 5, 147-183

Adhikari, K. R., Tan, Y.-C., Lai, J.-S., and Pant, D. (2009). Irrigation intervention: a strategy for conserving biodiversity and improving food security in royal chitwan national park buffer zone, Nepal. Irrig. Drain. 58, 522-537. doi: 10.1002/ird.443

Agrawal, A., Cashore, B., Hardin, R., Shepherd, G., Benson, C., and Miller, D. (2013). Economic Contributions of Forests. Istanbul: United Nations Forum on Forests, $10^{\text {th }}$ Session.

Albala, C., Vio, F., Kain, J., and Uauy, R. (2002). Nutrition transition in Chile: determinants and consequences. Public. Health. Nutr. 5, 123-128. doi: 10.1079/PHN2001283

Amundson, R., Berhe, A. A., Hopmans, J. W., Olson, C., Sztein, A. E., and Sparks, D. L. (2015). Soil and human security in the 21st century. Science 348:1261071. doi: 10.1126/science.12 61071

Anaya, F. C., and Espírito-Santo, M. M. (2018). Protected areas and territorial exclusion of traditional communities: analyzing the social impacts of environmental compensation strategies in Brazil. Ecol. Soc. 23:8. doi: 10.5751/ES-09850-230108

Andrade, G. S. M., and Rhodes, J. R. (2012). Protected areas and local communities: an inevitable partnership toward successful conservation strategies? Ecol. Soc. 17:14. doi: 10.5751/ES-05216-170414

Arjunan, M., Holmes, C., Puyravaud, J. P, and Davidar, P. (2006). Do developmental initiatives influence local attitudes toward conservation? A and forest conservation at the landscape scale could have significant potential both conserve biodiversity and ensure a more sustainable agricultural production; indeed, taking the "whole earth" approach advocated by (Büscher and Fletcher, 2019). Such an approach could also have significant longterm impacts on the nutrition and health of millions, if not billions of people (Gordon et al., 2016; Campanhola and Pandey, 2019) while ensuring the rights to access to such healthy and nutritious food in wild, and often protected, habitats are increasingly uncontested.

\section{AUTHOR CONTRIBUTIONS}

TS conceived of and secured funding for the larger body of work that provided the background evidence for this research. He designed the basic structure of paper and revised the first draft post-peer review. WV assisted with a broader literature review and drafted an early version of the paper.

\section{ACKNOWLEDGMENTS}

The authors are grateful to the Associate Editor of this special issue, Amy Ickowitz, for comments on an earlier version of this paper. Two reviewers also provided useful comments and suggestions. Funding for the participation of TS in this research as provided by USAID's Biodiversity earmark as well as a start-up grant from the University of British Columbia. The latter funding also provided support to $\mathrm{WV}$. case study from the Kalakad-Mundanthurai tiger reserve, India. Jour. Environ. Manage. 79, 188-197. doi: 10.1016/j.jenvman.2005.06.007

Asprilla-Perea, J., and Díaz-Puente, J. M. (2019). Importance of wild foods to household food security in tropical forest areas. Food. Secur. 11, 15-22. doi: 10.1007/s12571-018-0846-8

Banerjee, A. (2012). Is wildlife tourism benefiting Indian protected areas? A survey. Curr. Issues Tour. 15, 211-227. doi: 10.1080/13683500.2011.599367

Baudron, F., Gergel, S., Groot, J., Powell, B., Tomscha, S., and Sunderland, T. (2019). Testing the various pathways linking forest cover to dietary diversity in tropical landscapes. Front. Sust. Food Syst. 3:97. doi: 10.3389/fsufs.2019.00097

Bennett, N. J., and Dearden, P. (2014). Why local people do not support conservation: community perceptions of marine protected area livelihood impacts, governance and management in Thailand. Mar. Policy 44, 107-116. doi: 10.1016/j.marpol.2013.08.017

Binnema, T., and Niemi, M. (2006). "Let the line be drawn now": wilderness, conservation, and the exclusion of aboriginal people from Banff national park in Canada. Environ. Hist. 11, 724-750. doi: 10.1093/envhis/11.4.724

Blaney, S., Beaudry, M., and Latham, M. (2009). Contribution of natural resources to nutritional status in a protected area of Gabon. Food Nutr. Bull. 30, 49-62. doi: 10.1177/156482650903000105

Boedecker, J., Termote, C., Assogbadjo, A. E., Damme, P. V., and Lachat, C. (2014). Dietary contribution of wild edible plants to women's diets in the buffer zone around the Lama forest, Benin - an underutilized potential. Food. Sec. 6, 833-849. doi: 10.1007/s12571-014-0396-7

Brockington, D. (2002). Fortress Conservation. The Preservation of the Mkomazi Game Reserve, Tanzania. Oxford: James Currey.

Brockington, D., Igoe, J., and Schmidt-Soltau, K. (2006). Conservation, human rights, and poverty reduction. Conserv. Biol. 20, 250-252. doi: 10.1111/j.1523-1739.2006.00335.x 
Broegaard, R., Rasmussen, L., Dawson, N., Mertz, O., Vongvisouk, T., and Grogan, K. (2016). Wild food collection and nutrition under commercial agriculture expansion in agriculture-forest landscapes. For. Pol. Econ. 84, 92-101. doi: 10.1016/j.forpol.2016.12.012

Büscher, B., and Fletcher, R. (2019). Towards convivial conservation. Cons. Soc. 17, 283-296. doi: 10.4103/cs.cs_19_75

Buscher, B., Fletcher, R., Brockington, D., Sandbrook, C., Adams, W., Campbell, L., et al. (2017). Half-earth or whole earth? Radical ideas for conservation, and their implications. Oryx 51, 407-410. doi: 10.1017/S0030605316001228

Campanhola, C., and Pandey, S. (eds.). (2019). Sustainable Food and Agriculture: An Integrated Approach. Washington, DC: Academic Press.

Campbell, B., Beare, D., Bennett, E., Hall-Spencer, J., Ingram, J., Jaramillo, F., et al. (2017). Agriculture production as a major driver of the earth system exceeding planetary boundaries. Ecol. Soc. 22:8. doi: 10.5751/ES-09595-220408

Campese, J., Sunderland, T., Greiber, T., and Oviedo, G. (eds.). (2009). Rights Based Approaches: Exploring Issues and Opportunities for Conservation. Centre for International Forestry Research, Bogor.

Cawthorn, D. M., and Hoffman, L. C. (2015). The bushmeat and food security nexus: a global account of the contributions, conundrums and ethical collisions. Food. Res. Int. 76, 906-925. doi: 10.1016/j.foodres.2015.03.025

Chhatre, A., and Agrawal, A. (2009). Trade-offs and synergies between carbon storage and livelihood benefits from forest commons. Proc. Natl. Acad. Sci. U.S.A. 106, 17667-17670. doi: 10.1073/pnas.0905308106

Clements, T., Suon, S., Wilkie, D. S., and Milner-Gulland, E. J. (2014). Impacts of protected areas on local livelihoods in Cambodia. World Dev. 64, S125-S134. doi: 10.1016/j.worlddev.2014.03.008

Cox, R. L., and Underwood, E. C. (2011). The importance of conserving biodiversity outside of protected areas in mediterranean ecosystems. PLoS ONE 6:e14508. doi: 10.1371/journal.pone.0014508

Crittenden, A. N., and Schnorr, S. L. (2016). Current views on hunter-gatherer nutrition and the evolution of the human diet. Am. J. Phys. Anthropol. 162, 84-109. doi: 10.1002/ajpa.23148

Curtis, P. G., Slay, C. M., Harris, N. L., Tyukavina, A., and Hansen, M. C. (2018). Classifying drivers of global forest loss. Science 361, 1108-1111. doi: 10.1126/science.aau3445

Damman, S., Eide, W. B., and Kuhnlein, H. V. (2008). Indigenous peoples' nutrition transition in a right to food perspective. Food Policy 33, 135-155. doi: 10.1016/j.foodpol.2007.08.002

Darnton-Hill, I., and Coyne, E. T. (1998). Feast and famine: socioeconomic disparities in global nutrition and health. Public Health Nutr. 1, 23-31. doi: 10.1079/PHN19980005

Dawson, I. K., Attwood, S. J., Park, S. E., Jamnadass, R., Powell, W., Sunderland, T., et al. (2019). Contributions of biodiversity to the sustainable intensification of food production. Glob. Food Sec. 21, 23-37. doi: 10.1016/j.gfs.2019.07.002

DeClerck, F. A., Fanzo, J., Palm, C., and Remans, R. (2011). Ecological approaches to human nutrition. Food Nutr. Bull. 32, S41-S50. doi: $10.1177 / 15648265110321 S 106$

Desmet, E. (2016). Identifying rights-holders in natural resource regimes: a critical assessment of the peruvian protected areas legislation. Hague J. Rule Law 8, 135-154. doi: 10.1007/s40803-016-0027-9

Dounias, E., and Froment, A. (2006). When forest-based hunter-gatherers become sedentary: Consequences for diet and health. Unasylva 57, 26-33.

Dounias, E., Selzner, A., Koizumi, M., and Levang, P. (2007). From sago to rice, from forest to town: the consequences of sedentarization for the nutritional ecology of Punan former hunter-gatherers of Borneo. Food. Nutr. Bull. 28, 294-302. doi: 10.1177/1564826507028 $2 \mathrm{~S} 208$

Fa, J. E., Albrechtsen, L., Johnson, P. J., and Macdonald, D. W. (2009). Linkages between household wealth, bushmeat and other animal protein consumption are not invariant: evidence from Rio Muni, equatorial Guinea. Anim. Conserv. 12, 599-610. doi: 10.1111/j.1469-1795.2009.00289.x

Fa, J. E., Olivero, J., Real, R., Farfán, M. A., Márquez, A. L., Vargas, J. M., et al. (2015). Disentangling the relative effects of bushmeat availability on human nutrition in central Africa. Sci. Rep. 5:8168. doi: 10.1038/srep08168

FAO (2014a). The State of the World's Forest Genetic Resources. Food and Agriculture Organisation, Rome.

FAO (2014b). The State of Food and Agriculture: Innovation in Family Farming. Food and Agriculture Organisation, Rome.
Fischer, J., Abson, D. J., Bergsten, A., Collier, N., Dorresteijn, I., Hanspach, J., et al. (2017). Reframing the food-biodiversity challenge. Trends Ecol. Evol. 32, 335-345. doi: 10.1016/j.tree.2017.02.009

Galway, L. P., Acharya, Y., and Jones, A. D. (2018). Deforestation and child diet diversity: a geospatial analysis of 15 Sub-Saharan African countries. Health Place 51, 78-88. doi: 10.1016/j.healthplace.2018.03.002

Garnett, S. T., Burgess, N. D., Fa, J. E., Fernández-Llamarazes, A., Molnár, Z., Robinson, C., et al. (2018). A spatial overview of the global importance of indigenous lands for conservation. Nat. Sustain. 1, 369-374. doi: 10.1038/s41893-018-0100-6

Gibbs, H. K., Ruesch, A. S., Achard, F., Clayton, M. K., Holmgren, P., Ramankutty, N., et al. (2010). Tropical forests were the primary sources of agricultural land in the 1980s and 1990s. Proc. Natl. Acad. Sci. U.S.A. 107, 16732-16737. doi: 10.1073/pnas.0910275107

Givá, N., and Raitio, K. (2017). 'Parks with people' in Mozambique: community dynamic responses to human-elephant conflict at Limpopo national park. J. South. Afr. Stud. 43, 1199-1214. doi: 10.1080/03057070.2017.13 74810

Golden, C. D., Bonds, M. H., Brashares, J. S., Rasolofoniaina, B. J., and Kremen, C. (2014). Economic valuation of subsistence harvest of wildlife in Madagascar. Conserv. Biol. 28, 234-243. doi: 10.1111/cobi.12174

Golden, C. D., Fernald, L. C., Brashares, J. S., Rasolofoniaina, B. J., and Kremen, C. (2011). Benefits of wildlife consumption to child nutrition in a biodiversity hotspot. Proc. Natl. Acad. Sci. U.S.A. 108, 19653-19656. doi: $10.1073 /$ pnas. 1112586108

Gordon, I., Prins, H., and Squire, G. (eds.). (2016). Food Production and Nature Conservation: Conflicts and Solutions. Oxford, UK: Earthscan Routledge.

Gray, C. L., Hill, S. L., Newbold, T., Hudson, L. N., Börger, L., Contu, S., et al. (2016). Local biodiversity is higher inside than outside terrestrial protected areas worldwide. Nat. Comms. 7:12306. doi: 10.1038/ncomms12306

Hall, C., Macdiarmid, J., Matthews, R., Smith, P., Hubbard, S., and Dawson, T. (2019). The relationship between forest cover and diet quality: a case study of southern Malawi. Food Sec. 11, 635-650. doi: 10.1007/s12571-019-00923-0

Harari, Y. N. (2016). Sapiens: A Brief History of Mankind. London: Signal.

He, M., and Cliquet, A. (2014), Sustainable development through a rights-based approach to conserve protected areas in China. China-EU Law J. 3, 143-163. doi: 10.1007/s12689-013-0031-7

Heywood, V. H. (2011). Ethnopharmacology, food production, nutrition and biodiversity conservation: towards a sustainable future for indigenous peoples. J. Ethnopharmacol. 137, 1-15. doi: 10.1016/j.jep.2011.05.027

Hickey, G. M., Pouliot, M., Smith-Hall, C., Wunder, S., and Nielsen, M. R. (2016). Quantifying the economic contribution of wild food harvests to rural livelihoods: A global-comparative analysis. Food Policy 62, 122-132. doi: 10.1016/j.foodpol.2016.06.001

HLPE (2017a). Sustainable Forestry for Food Security and Nutrition. A Report by the High Level Panel of Experts on Food Security and Nutrition of the Committee on World Food Security. Rome.

HLPE (2017b). Nutrition and Food Systems. A Report by the High Level Panel of Experts on Food Security and Nutrition of the Committee on World Food Security. Rome.

Holt-Giménez, E., Shattuck, A., Altieri, M., Herren, H., and Gleisssmen, S. (2012). We already grow enough food for 10 billion people - and still can't end hunger. J. Sustain. Agr. 36, 595-598. doi: 10.1080/10440046.2012.695331

Hutton, J. M., Adams, W. M., and Murombedzi, J. (2005). Back to the barriers? Changing narratives in biodiversity conservation. For. Dev. Stud. 2, 341-370. doi: 10.1080/08039410.2005.9666319

Ickowitz, A., Jones, A., Rowland, D., Powell, B., and Sunderland, T. (2019). Agricultural intensification, dietary diversity, and markets in the global food security narrative. Glob. Food Sec. 20, 9-16. doi: 10.1016/j.gfs.2018.11.002

Ickowitz, A., Powell, B., Salim, A., and Sunderland, T. (2014). Dietary quality and tree cover in Africa. Glob. Env. Change 24, 287-294. doi: 10.1016/j.gloenvcha.2013.12.001

Ickowitz, A., Powell, B., Salim, A., and Sunderland, T. (2016). The effect of tree cover on child nutrition in Indonesia: examining the relationship between tree cover and consumption of micronutrient-rich foods. PLoS ONE 11:e0154139. doi: 10.1371/journal.pone.0154139

IUCN (2005). The Durban Accord. IUCN. 219-223.

IUCN (2019). IUCN Annual Report 2018. IUCN. Gland. 
Johnson, K. B., Jacob, A., and Brown, M. E. (2013). Forest cover associated with improved child health and nutrition: evidence from the malawi demographic and health survey and satellite data. Glob. Health. Sci. Pract. 1, 237-248. doi: 10.9745/GHSP-D-13-00055

Kraak, A. L. (2018). Human rights-based approaches to world heritage conservation in bagan, myanmar: conceptual, political, and practical considerations. Int. J. Cult. Prop. 25, 111-133. doi: 10.1017/S09407391180 00012

Kuhnlein, H. V., Receveur, O., Soueida, R., and Egeland, G. M. (2004). Arctic indigenous peoples experience the nutrition transition with changing dietary patterns and obesity. J. Nutr. 134, 1447-1453. doi: 10.1093/jn/134. 6.1447

Levis, C., Costa, F. R., Bongers, F., Peña-Claros, M., Clement, C. R., Junqueira, A. B. et al. (2017). Persistent effects of pre-Columbian plant domestication on Amazonian forest composition. Science 355, 925-931. doi: $10.1126 /$ science.aal0157

Lourenço, A. E., Santos, R. V., Orellana, J. D., and Coimbra, C. E. (2008). Nutrition transition in Amazonia: obesity and socioeconomic change in the Suruí Indians from Brazil. Am. J. Hum. Biol. 20, 564-571. doi: 10.1002/ajhb.20781

Lupo K. D., Schmitt D. N., Kiahtipes C. A., Ndanga J. P., Young D. C., Simiti B. (2015). On inensive late holocene iron mining and production in the Northern Congo basin and the environmental consequences associated with metallurgy in central Africa. PLoS ONE 10:e0132632. doi: 10.1371/journal.pone.0132632

Mackelworth, P., and Carić, H. (2009). Gatekeepers of island communities: exploring the pillars of sustainable development. Environ. Dev. Sustain. 12, 463-480. doi: 10.1007/s10668-009-9205-4

Maezumi S. Y., Alves D., Robinson M., de Souza J. G., Levis C., Barnett R. L. et al. (2018). The legacy of 4,500 years of polyculture agroforestry in the eastern Amazon. Nat. Plants 4, 540-547. doi: 10.1038/s41477-018-0205-y

Massé, F. (2016). The political ecology of human-wildlife conflict: producing wilderness, insecurity, and displacement in the Limpopo national park. Conserv. Soc. 14, 100-111. doi: 10.4103/0972-4923.186331

Mehrabi, Z., Ellis, E., and Ramankutty, N. (2018). The challenge of feeding the world while conserving half the planet. Nat Sustain. 1, 409-412. doi: 10.1038/s41893-018-0119-8

Mollett, S., and Kepe, T. (2018). Land Rights, Biodiversity Conservation and Justice. London: Routledge.

Morales-Hidalgo, D., Oswalt, S. N., and Somanathan, E. (2015). Status and trends in global primary forest, protected areas, and areas designated for conservation of biodiversity from the global forest resources assessment 2015. For. Ecol. Manage. 352, 68-77. doi: 10.1016/j.foreco.2015.06.011

Naidoo R., Gerkey D., Hole D., Pfaff A., Ellis A. M., Golden C. D., et al. (2019). Evaluating the impacts of protected areas on human well-being across the developing world. Sci. Adv. 5:eaav3006. doi: 10.1126/sciadv.aav3006

Nakamura, E. M., and Hanazaki, N. (2017). Protected area establishment and its implications for local food security. Hum. Ecol. Rev. 23, 101-122. doi: 10.22459/HER.23.01.2017.06

N’Danikou, S., Vodouhe, R. S., Bellon, M. R., Sidibé, A., and Coulibaly, H. (2017). Foraging is determinant to improve smallholders' food security in rural areas in Mali, West Africa. Sustainability 9:2074. doi: 10.3390/su9112074

Neumann, R. (2002). Imposing wilderness. Struggles Over Livelihood and Nature Preservation in Africa. London, UK: University of California Press.

Newing, H., and Perram, A. (2019). What do you know about conservation and human rights? Oryx 53, 595-596. doi: 10.1017/S0030605319000917

Nielsen, M. R., Meilby, H., Smith-Hall, C., Poiliot, M., and Treue, T. (2018). The importance of wild meat in the global south. Ecol. Econ. 146, 696-705. doi: 10.1016/j.ecolecon.2017.12.018

Nyahongo, J. W., Holmern, T., Kaltenborn, B. P., and Røskaft, E. (2009). Spatial and temporal variation in meat and fish consumption among people in the western Serengeti, Tanzania: the importance of migratory herbivores. Oryx 43, 258-266. doi: 10.1017/S0030605307991127

Oldekop, J. A., Holmes, G., Harris, W. E., and Evans, K. L. (2016). A global assessment of the social and conservation outcomes of protected areas. Conserv. Biol. 30, 133-141. doi: 10.1111/cobi.12568

Osilisly, R., White, L., Bentaleb, I., Favier, C., Fontugne, M., Gillet, J.-F., et al. (2013). Climatic and cultural changes in the west Congo Basin forests over the past 5,000 years. Phil. Trans. Roy. Soc. B 368:20120304. doi: $10.1098 /$ rstb.2012.0304
Padoch, C., and Sunderland, T. (2014). Managing landscapes for food security and enhanced livelihoods: building upon a wealth of local experience. Unasylva 241, $3-13$.

Pattiselanno, F., and Lubis, M. I. (2014). Hunting at the abun regional marine protected areas: a link between wildmeat and food security. Hayati J. Biosci. 21, 180-186. doi: 10.4308/hjb.21.4.180

Perfecto, I., Vandermeer, J., and Wright. A. (2019). Nature's Matrix: Linking Agriculture, Biodiversity, Conservation and Food Security. London: Earthscan Routledge.

Popkin, B. M. (2001). The nutrition transition and obesity in the developing world. J. Nutr. 131, 871S-873S. doi: 10.1093/jn/131.3.871S

Pouliot, M., and Treue, T. (2013). Rural people's reliance on forests and the nonforest environment in West Africa: evidence from Ghana and Burkina Faso. World Dev. 43, 180-193. doi: 10.1016/j.worlddev.2012.09.010

Powell, B., Ickowitz, A., Termote, C., Thilsted, S., Sunderland, T., and Herforth, A. (2015). Strategies to improve diets with wild and cultivated biodiversity from across the landscape. Food Sec. 7, 535-554. doi: 10.1007/s12571-0150466-5

Rasmussen, L., Watkins, C., and Agrawal, A. (2017). Forest contributions to livelihoods in changing agriculture-forest landscapes. For. Pol. Econ. 84, 1-8. doi: 10.1016/j.forpol.2017.04.010

Rasmussen, L. V., Rhemtulla, J. M., Fagan, M. E., Ickowitz, A., Wood, S. L. R., Kennedy, G., et al. (2019). Forest pattern, not just amount, influences dietary quality in five African countries. Glob. Food Sec. 100331. doi: 10.1016/j.gfs.2019.100331

Rasolofson, R., Hanauer, M., Pappinen, A., Fisher, B., and Ricketts, T. (2018). Impact of forests on children's diets across 27 developing countries. Sci. Adv. 4:eaat2853. doi: 10.1126/sciadv.aat2853

Reed, J., van Vianen, J., Deakin, E., and Barlow, J., Sunderland, T. (2016). Integrated landscape approaches to managing social and environmental issues in the tropics: learning from the past to guide the future. Glob. Change Biol. 7, 2550-2554. doi: 10.1111/gcb.13284

Reed, J., van Vianen, J., Foli, S., Clendinning, J., Yang, K., Petrokovsky, G., et al. (2017). Trees for life: the ecosystem service contribution of trees to food production and livelihoods in the tropics. For. Pol. Econ. 84, 62-71. doi: 10.1016/j.forpol.2017.01.012

Rentsch, D., and Damon, A. (2013). Prices, poaching, and protein alternatives: An analysis of bushmeat consumption around Serengeti National Park, Tanzania. Ecol. Econ. 91, 1-9. doi: 10.1016/j.ecolecon.2013.03.021

Reuter, K. E., Randell, H., Wills, A. R., and Sewall, B. J. (2016). The consumption of wild meat in Madagascar: drivers, popularity and food security. Environ. Conserv. 43, 273-283. doi: 10.1017/S0376892916000059

Reyes-Garcia, V., Powell, B., Díaz-Reviriego, I., Fernández-Llamazares, Á., Gallois, S., and Gueze, M. (2019). Dietary transitions among three contemporary hunter-gatherers across the tropics. Food Sec. 11, 109-122. doi: 10.1007/s12571-018-0882-4

Ricciardi, V., Ramunkutty, N., Mehrabi, Z., Jarvis, L., and Chookolingo, B. (2018). How much of the world's food do smallholders produce? Glob. Food Sec. 17, 64-72. doi: 10.1016/j.gfs.2018.05.002

Rosendo, S., Brown, K., Joubert, A., Jiddawi, N., and Mechisso, M. (2011). A clash of values and approaches: a case study of marine protected area planning in Mozambique. Ocean Coast Manag. 54, 55-65. doi: 10.1016/j.ocecoaman.2010.10.009

Rowland, D., Ickowitz, A., Powell, B., Nasi, R., and Sunderland, T. (2017). Forest foods and healthy diets: quantifying the contributions. Environ. Conserv. 44, 102-114. doi: 10.1017/S0376892916000151

Savage, A., McIver, L., and Schubert, L. (2019). Review: the nexus of climate change, food and nutrition security and diet-related non-communicable diseases in Pacific Island Countries and Territories. Clim. Dev. 1-14. doi: 10.1080/17565529.2019.1605284

Sayer, J., Sunderland, T., Ghazoul, J., Pfund, J.-L., Sheil, D., Meijaard, E., et al. (2013). The landscape approach: ten principles to apply at the nexus of agriculture, conservation and other competing land-uses. Proc. Natl. Acad. Sci. U.S.A. 110, 8345-8348. doi: 10.1073/pnas.1210595110

Schulte-Herbrüggen, B., Cowlishaw, G., Homewood, K., and Rowcliffe, J. M. (2013). The importance of bushmeat in the livelihoods of West African cashcrop farmers living in a faunally-depleted landscape. PLOS ONE 8:e72807. doi: 10.1371/journal.pone.0072807 
Shafer, C. L. (2015). Cautionary thoughts on IUCN protected area management categories V-VI. Glob. Ecol. Conserv. 3, 331-348. doi: 10.1016/j.gecco.2014.12.007

Smith, E. A. Bettinger, R. L., Bishop, C. A., Blundell, V., Cashdan, E., Casimir, M. J. et al. (1983). Anthropological applications of optimal foraging theory: a critical review. Curr. Anthropol. 24, 625-651. doi: 10.1086/203066

Springmann M., Clark M., Mason-D’Croz D., Wiebe K., Bodirsky B. L., Lassaletta L. et al. (2018). Options for keeping the food system within environmental limits. Nature 562, 519-525. doi: 10.1038/s41586-018-0594-0

Sunderland, T. C. H. (2011). Food security: why is biodiversity important? Int. For. Rev. 13, 265-274. doi: 10.1505/146554811798293908

Sylvester, O., Segura, A., and Davison-Hunt, I. (2016). The protection of biodiversity can conflict with food access for indigenous people. Cons. Soc. 14, 279-290. doi: 10.4103/0972-4923.191157

Tanentzap A. J., Lamb A., Walker S., Farmer A. (2015). Resolving conflicts between agriculture and the natural environment. PLoS Biol. 13:e1002242. doi: 10.1371/journal.pbio.1002242

Tata C. Y., Ickowitz A., Powell B., Colecraft E. K. (2019). Dietary intake, forest foods, and anemia in Southwest Cameroon. PLoS ONE 14:e0215281. doi: 10.1371/journal.pone.0215281

Temsah, G., Johnson, K., Evans, T., and Adams, D. K. (2018). Benefits of biodiverse marine resources to child nutrition in differing developmental contexts in Hispaniola. PLoS ONE 13, 1-24. doi: 10.1371/journal.pone.0197155

Timko, J. A., and Satterfield, T. (2008). Seeking social equity in national parks: experiments with evaluation in Canada and South Africa. Conserv. Soc. 6, 238-254. doi: 10.4103/0972-4923.49216

Turner, N. J., and Turner, K. L. (2008). "Where our women used to get the food": cumulative effects and loss of ethnobotanical knowledge and practice; case study from coastal British Columbia. Botany 86, 103-115. doi: 10.1139/B07-020

Van Vliet, N. V., Nebesse, C., and Nasi, R. (2015). Bushmeat consumption among rural and urban children from province orientale, democratic republic of Congo. Oryx 49, 165-174. doi: 10.1017/S0030605313000549

Vandermeer, J., Aga, A., Allgeier, J., Badgley, C., Baucom, R., Blesh, J., et al. (2018). Feeding prometheus: an interdisciplinary approach for solving the global food crisis. Front. Sustain. Food Syst. 2:39. doi: 10.3389/fsufs.2018. 00039
Vinceti, B., Termote, C., Ickowitz, A., Powell, B., Kehlenbeck, K., and Hunter, D. (2013). The contribution of forests and trees to sustainable diets. Sustainability 5, 4797-4824. doi: 10.3390/su5114797

Vira, B., Wildburger, C., and Mansourian, S. (eds.). (2015). Forests, Trees and Landscapes for Food Security and Nutrition. A Global Assessment Report. IUFRO World Series, Vol. 33. Vienna, 172.

Walsh-Dilley, M., Wolford, W., and McCarthy, J. (2016). Rights for resilience: food sovereignty, power, and resilience in development practice. Ecol. Soc. 21: doi: 10.5751/ES-07981-210111

Weerasekara, P. C., Withanachchi, C. R., Ginigaddara, G. A. S., and Ploeger, A. (2018). Nutrition transition and traditional food cultural changes in Sri Lanka during colonization and post-colonization. Foods 7, 1-18. doi: 10.3390/foods7070111

West, P., Igoe, J., and Brockington, D. (2006). Parks and peoples: the social impact of protected areas. Ann. Rev. Anthropol. 35, 251-277. doi: 10.1146/annurev.anthro.35.081705.123308

Wilson, E. O. (2016). Half-Earth: Our Planet's Fight for Life. New York, NY: Liveright Publishing Corporation.

Wunder, S., Angelsen, A., and Belcher, B. (2014). Forests, livelihoods, and conservation: broadening the empirical base. World Dev. 64, S1-S11. doi: 10.1016/j.worlddev.2014.03.007

Young H., Taylor A., Way S. A., Leaning J. (2004). linking rights and standards: the process of developing "rights based" minimum standards on food security, nutrition and food aid. Disasters 28, 142-159. doi: $10.1111 / j .0361-3666.2004 .00249 . x$

Conflict of Interest: The authors declare that the research was conducted in the absence of any commercial or financial relationships that could be construed as a potential conflict of interest.

Copyright () 2020 Sunderland and Vasquez. This is an open-access article distributed under the terms of the Creative Commons Attribution License (CC BY). The use, distribution or reproduction in other forums is permitted, provided the original author(s) and the copyright owner(s) are credited and that the original publication in this journal is cited, in accordance with accepted academic practice. No use, distribution or reproduction is permitted which does not comply with these terms. 